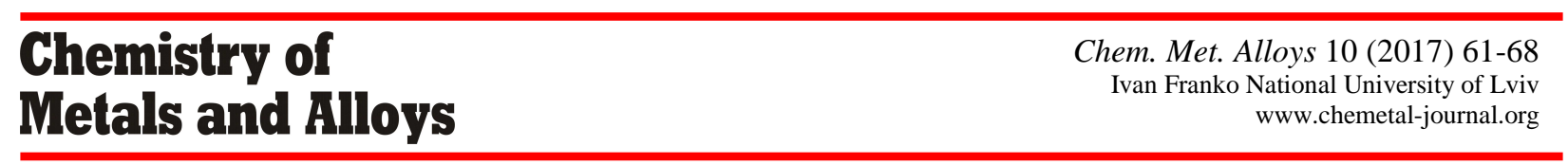

\title{
Influence of doping elements on the electrochemical hydrogenation efficiency of $\mathrm{Tb}_{2} \mathrm{Ni}_{17}$-based phases
}

\author{
Vasyl KORDAN ${ }^{1}$, Vitaliy NYTKA ${ }^{1}$, Grzegorz KOVALCZYK ${ }^{2}$, Agnieszka BALINSKA ${ }^{2}$, Oksana ZELINSKA ${ }^{1}$, \\ Roman SERKIZ ${ }^{3}$, Volodymyr PAVLYUK ${ }^{1,2}$ \\ ${ }^{1}$ Department of Inorganic Chemistry, Ivan Franko National University of Lviv, \\ Kyryla i Mefodiya St. 6, 79005 Lviv, Ukraine \\ ${ }^{2}$ Czestochowa Jan Dlugosz University, Institute of Chemistry, Environmental Protection and Biotechnology, \\ Armii Krajowej Ave. 13/15, 42200 Czestochowa, Poland \\ ${ }^{3}$ Scientific-Technical and Educational Center of Low-Temperature Studies, \\ Ivan Franko National University of Lviv, Drahomanova St. 50, 79005 Lviv, Ukraine \\ * Corresponding author. E-mail: kordan50@gmail.com
}

Received May 16, 2017; accepted June 27, 2017; available on-line April 1, 2018

Electrochemical hydrogenation of the phases $\mathrm{Tb}_{2} \mathrm{Ni}_{17-x} M_{x}, x \approx 1(M=\mathrm{Li}, \mathrm{Mg}, \mathrm{Al}, \mathrm{Ge}, \mathrm{Sn}, \mathrm{Sb}, \mathrm{Bi}, \mathrm{Co})$ that crystallize in the $\mathrm{Th}_{2} \mathrm{Ni}_{17}$-type structure was investigated for the first time. The phases containing the $s$-element $\mathrm{Li}$ or $\mathrm{Mg}$, or a mixture of these $(\mathrm{Li}, \mathrm{Mg}$ ) as doping element showed the best Coulomb efficiency. Under the conditions of the experiment $(10 \mathrm{~mA} \cdot \mathrm{h}$ charge $)$ pure $\mathrm{Tb}_{2} \mathrm{Ni}_{17}$ absorbed approximately $0.67 \mathrm{H} / \mathrm{f}$.u. $(50.0 \%$ efficiency), the Li-containing phase approximately $1.43 \mathrm{H} / \mathrm{f} . \mathrm{u} .(86.0 \%)$, the Mg-containing phase $1.37 \mathrm{H} / \mathrm{f} . \mathrm{u}$. (76.3\%), and the phases with a mixture of $\mathrm{Li}$ and $\mathrm{Mg}$, namely $\mathrm{Tb}_{2} \mathrm{Ni}_{16} \mathrm{Li}_{0.4} \mathrm{Mg} \mathrm{gg}_{0.6}$ and $\mathrm{Tb}_{2} \mathrm{Ni}_{15.6} \mathrm{Li}_{0.6} \mathrm{Mg}_{0.8}, 1.46 \mathrm{H} /$ f.u. $(91.5 \%)$ and $1.50 \mathrm{H} /$ f.u. (95.0 \%), respectively. The phases with $p$-elements such as $\mathrm{Al}$, Ge, Sn revealed interaction of the surface with the electrolyte, but showed structural and corrosion stability over 30 charge-discharge cycles. The Al-containing phase absorbed 1.09 H/f.u. $(67.8 \%$ efficiency), the Ge-containing phase 1.05 H/f.u. $(63.1 \%)$, the Sn-containing phase $0.76 \mathrm{H} /$ f.u. $(52.5 \%)$. the Sb-containing phase $1.24 \mathrm{H} / \mathrm{f}$.u. $(75.5 \%)$, and the Bi-containing phase $1.46 \mathrm{H} / \mathrm{f}$.u. $(79.8 \%)$. Cobalt was added to the initial binary compound in larger amounts (up to 26.3 at.\%) because smaller quantities did not increase the amount of absorbed hydrogen, but even high Co contents did not affect the results significantly $(0.98$ H/f.u., $59.5 \%$ efficiency). In all cases intercalation of hydrogen occurred in octahedral voids (Wyckoff position $6 \mathrm{~h}$ ) of the initial structures, i.e. the coordination polyhedron of the $\mathrm{H}$-atoms was an octahedron $\left[\underline{H} \mathrm{~Tb}_{2}(\mathrm{Ni}, M)_{4}\right]$. Electron microprobe analysis showed that the electrodes on the basis of $\mathrm{Tb}_{2} \mathrm{Ni}_{17-x} M_{x}$ were stable in the electrolyte over 30-50 cycles of electrochemical processes. Cyclic voltamperometry, impedance measurements and corrosion studies of the electrode materials also confirmed their stability in alkaline solutions of electrolyte $(6 \mathrm{M} \mathrm{KOH})$.

Intermetallic compound / Solid solution / Electrochemical hydrogenation / Electrode material /Ni-MH battery

Introduction

Intermetallic compounds on the basis of rare-earth and transition metals show a variety of interesting physical and chemical properties such as electric conductivity, thermal conductivity, magnetism, and catalytic properties. If the compounds contain $\mathrm{Mg}$ or a transition metal and their crystal structures are characterized by large voids, they can absorb hydrogen, forming hydrides. These hydrides often keep the structure of the initial intermetallic compounds, forming solid solutions with inclusion of $\mathrm{H}$-atoms. In other cases the hydrides are individual compounds with a structure different from that of the initial phase. If these compounds are stable in an alkaline solution of the electrolyte $6 \mathrm{M} \mathrm{KOH}$ they can be used as electrode materials in $\mathrm{Ni}-\mathrm{MH}$ batteries [1-6].

Some intermetallics on the basis of rare-earth metals absorbing a large amount of hydrogen were studied in [7-9]. Stetskiv et al. [10] carried out electrochemical hydrogenation and investigated the corrosion behavior of $\mathrm{La}_{5-x} M_{x}(T=\mathrm{Co}, \mathrm{Ni}$ and $M=\mathrm{Al}, \mathrm{Ge}, \mathrm{Li})$ phases crystallizing in the $\mathrm{CaCu}_{5}$-type structure. Doping of the $\mathrm{LaCo}_{5}$ and $\mathrm{LaNi}_{5}$ binary phases by $\mathrm{Al}$, $\mathrm{Ge}$ or $\mathrm{Li}$ improved the corrosion resistance, thermal stability and absorption capacity during the electrochemical hydrogenation. The related phases $\mathrm{LaNi}_{4.8} \mathrm{Al}_{0.2}$ and $\mathrm{LaNi}_{4.8} \mathrm{Al}_{0.1} \mathrm{Li}_{0.1}$ were investigated by Giza et al. [11]. Partial substitution of 
$\mathrm{Li}$ for $\mathrm{Al}$ led to an increase of the amount of absorbed hydrogen and to a decrease of the plateau pressures. On the basis of potentiokinetic polarization characteristics, it was demonstrated that the presence of $\mathrm{Li}$ in the alloy was advantageous from the point of view of corrosion resistance. There is also information about such doping elements as $\mathrm{Al}, \mathrm{Zn}, \mathrm{Sb}, \mathrm{Bi}, \mathrm{Li}$, and $\mathrm{Mg}$ and their influence on the absorption and desorption processes [12-22]. In 2009 Giza et al. [20] noticed that doping of $\mathrm{LaCO}_{5}$-based alloys by small amounts of $\mathrm{Mg}, \mathrm{Sb}$ or $\mathrm{Bi}$ increases the effectiveness of the hydrogen absorption as compared to the intermetallic compound $\mathrm{LaCo}_{5}$ Typical potentiokinetic polarization curves in a $6 \mathrm{M}$ potassium hydroxide solution showed that such substitution resulted in lower anodic currents in the passivation range. The substitution did not significantly affect the shape of the potentiokinetic polarization curves at $\mathrm{pH} 2$ and 7. Partial replacement of cobalt by bismuth in $\mathrm{LaCo}_{5}$ increased the effectiveness of the absorption of cathodically evolved hydrogen in strong alkaline solutions.

The authors of [23-26] studied alloys with $\mathrm{Th}_{2} \mathrm{Ni}_{17}$-type structures. Levytskyy et al. [23] investigated gas hydrogenation of $\mathrm{Dy}_{2} M_{17}(M=\mathrm{Co}$, $\mathrm{Ni}$ ) intermetallics. According to their results the Co-containing phase absorbed $3.4 \mathrm{H} / \mathrm{f}$.u. and the Ni-containing phase $3.5 \mathrm{H} / \mathrm{f}$.u. under $5 \mathrm{MPa}$ hydrogen pressure, preserving the crystal structures of the initial compounds. Tereshina et al. [24] noticed that some magnetic characteristics (such as the Curie temperature and magnetocrystalline anisotropy) were highly sensitive to the concentration of hydrogen in $\mathrm{Dy}_{2} \mathrm{Fe}_{17} \mathrm{H}_{x}$ and exhibited dramatic changes with increasing H-content. They explained this by a model that took into consideration the interaction of the quadrupole and $4 f$ electron magnetic moments of the rare-earth ions with the interstitial hydrogen atoms. Wirth et al. [25] confirmed that inclusion of hydrogen into the structure of $R_{2} \mathrm{Fe}_{17}(R=\mathrm{Y}, \mathrm{Sm}$ and $\mathrm{Gd})$ intermetallic compounds causes significant anisotropy of the physical properties. Isnar et al. [26] investigated several deuterides $R_{2} \mathrm{Fe}_{17} \mathrm{D}_{x}(R=\mathrm{Ce}, \mathrm{Nd}, \mathrm{Ho})$ by neutron diffraction and found that the octahedral site in $6 h$ is favored in the hydrides (deuterides). Substantial occupation of the tetrahedral site in $12 i$ only occurred for higher $\mathrm{H}$ content $(x>3)$.

Ternary alloys from the $\mathrm{Tb}_{2} \mathrm{Ni}_{17}-\mathrm{Tb}_{2} \mathrm{Al}_{17}$ section, where the boundary phases crystallize in structures of the hexagonal $\mathrm{Th}_{2} \mathrm{Ni}_{17}$-type and form a continuous series of solid solutions, were studied by several authors [27-30]. All the experimental work was focused on the study of the magnetic behavior of these phases. Also the intermetallic compounds $R_{2} \mathrm{Co}_{17-x} \mathrm{Ga}_{x}$ were studied with the purpose to investigate their magnetic properties [31].

There is not much information available on the solubility of third components such as $\mathrm{Li}, \mathrm{Ge}, \mathrm{Sn}, \mathrm{Sb}$, $\mathrm{Bi}$, or $\mathrm{Co}$ in the compound $\mathrm{Tb}_{2} \mathrm{Ni}_{17}$. Solokha [32] claimed that the binary compound $\mathrm{Tb}_{2} \mathrm{Ni}_{17}$ does not form any solid solutions with $\mathrm{Mg}$. However, in our previous works $[33,34]$ we found that the solubility of $\mathrm{Mg}$ in $\mathrm{Tb}_{2} \mathrm{Ni}_{17}$ is $\sim 8$ at. $\%$ and the solubility of $\mathrm{Sn}$ in the same compound $\sim 5$ at.\%. Moreover, we studied these $\mathrm{Mg}$ - and Sn-containing alloys as negative electrodes for Ni-MH batteries at a charge of $8 \mathrm{~mA} \cdot \mathrm{h}$. The Coulomb efficiency for the pure binary $\mathrm{Tb}_{2} \mathrm{Ni}_{17}$ phase and for the $\mathrm{Mg}$ - and Sn-containing ternary phases $[33,34]$ was the same as for the title phases, which were studied at $10 \mathrm{~mA} \cdot \mathrm{h}$. We also studied the influence $\mathrm{Li}$ and $\mathrm{Al}$ as dopants on the processes of electrochemical and gas hydrogenation of metallic magnesium and noticed lower temperature and lower equilibrium pressure for gas hydrogenation, and better stability of the doped alloys during the chargedischarge processes as compared to pure $\mathrm{Mg}$. By hydrogenation of the $\mathrm{Mg}_{76} \mathrm{Li}_{12} \mathrm{Al}_{12}$ phase we obtained the composition $\mathrm{Mg}_{76} \mathrm{Li}_{12} \mathrm{Al}_{12} \mathrm{H}_{74}$ with a hexagonal structure, further hydrogenation of which led to a change of the structure to orthorhombic [35-37].

The main purpose of this research was to study the effect of doping of $\mathrm{Tb}_{2} \mathrm{Ni}_{17}$ by some $s-, p$ - and $d$-elements on the amount of absorbed hydrogen and the electrochemical characteristics of the alloys. We compared the Coulomb efficiency of Ni-MH prototype batteries with different $\mathrm{Tb}_{2} \mathrm{Ni}_{17-x} M_{x}$ alloys as negative electrodes. We also studied the stability of the electrode materials in the electrolyte $(6 \mathrm{M} \mathrm{KOH})$ and the change of the surface morphology during the electrochemical processes.

\section{Experimental}

Terbium, nickel, tin, antimony, magnesium, lithium, aluminum, germanium, bismuth, and cobalt, with a nominal purity of more than $99.9 \mathrm{wt} \%$, were used as starting materials. Alloys with the compositions $\mathrm{Tb}_{10.5} \mathrm{Ni}_{89.5}, \quad \mathrm{~Tb}_{10.5} \mathrm{Ni}_{84.2} \mathrm{Li}_{2} \mathrm{Mg}_{3.3}, \quad \mathrm{~Tb}_{10.5} \mathrm{Ni}_{82.5} \mathrm{Li}_{3} \mathrm{Mg}_{4}$, $\mathrm{Tb}_{10.5} \mathrm{Ni}_{82.2} \mathrm{Mg}_{7.3}, \quad \mathrm{~Tb}_{10.5} \mathrm{Ni}_{84.2} \mathrm{Al}_{5.3}, \quad \mathrm{~Tb}_{10.5} \mathrm{Ni}_{85.2} \mathrm{Ge}_{4.3}$, $\mathrm{Tb}_{10.5} \mathrm{Ni}_{84.2} \mathrm{Sn}_{5.3}, \mathrm{~Tb}_{10.5} \mathrm{Ni}_{83.2} \mathrm{Sb}_{6.3}, \mathrm{~Tb}_{10.5} \mathrm{Ni}_{85.8} \mathrm{Bi}_{4}$, and $\mathrm{Tb}_{10.5} \mathrm{Ni}_{63.2} \mathrm{Co}_{26.3}$ were synthesized by arc melting of pure components under an argon atmosphere. To reach homogeneity the samples were sealed in silica ampoules, annealed at 400 and $600^{\circ} \mathrm{C}$ for 2 months and finally quenched in cold water. In the case of the lithium-, magnesium-, antimony-, and bismuthcontaining alloys, the above-mentioned metal was added in excess of about 10-20 wt.\%, and the components of the samples were first pressed into pellets and then melted to avoid loss of these metals because of their low boiling temperatures.

Phase analysis of the alloys, before and after the electrochemical processes, was carried out by powder $\mathrm{X}$-ray diffraction using a DRON-2.0M diffractometer (Fe $K \alpha$-radiation). The lattice parameters of the observed phases were refined using the LATCON [38] and PowderCell [39] programs.

Electrochemical hydrogenation of the $\mathrm{Tb}_{2} \mathrm{Ni}_{17}$ binary compound and its ternary derivatives 
$\mathrm{Tb}_{2} \mathrm{Ni}_{17-x} M_{x}(M=\mathrm{Li}, \mathrm{Mg}, \mathrm{Al}, \mathrm{Ge}, \mathrm{Sn}, \mathrm{Sb}, \mathrm{Bi}, \mathrm{Co})$ was carried out in 2- and 3-electrode Swagelok-type cells. The battery prototype consisted of a composite negative electrode containing $0.3 \mathrm{~g}$ of alloy and a positive counter-electrode containing $\mathrm{Ni}(\mathrm{OH})_{2}$ (a mixture of the $\alpha$ - and $\beta$-modification) with graphite for better electric conductivity. Amorphous $\alpha-\mathrm{Ni}(\mathrm{OH})_{2}$ is electrochemically active and can transform into crystalline $\beta-\mathrm{Ni}(\mathrm{OH})_{2}$ by drying and dehydration [1].

A separator made from pressed cellulose soaked in $6 \mathrm{M} \mathrm{KOH}$ as an electrolyte was placed between the electrodes to avoid contact between them. Testing of the batteries was carried out in galvanostatic regime over 30-50 cycles, using a galvanostat MTech G410-2 [40]. A potentiostat-galvanostat from $\mathrm{CH}$ Instruments (Austin, TX, USA) was used to measure the cyclic voltamperometric, potentio-kinetic and impedance characteristics. The electrode materials were prepared by grinding the alloys into powders. Multi-cycle chronopotentiometric measurements were performed in 3-electrode Swagelok-type cells. The specific capacity and the Coulomb efficiency vs. the number of cycles for the tested alloys were investigated in a 2-electrode cell (coin prototype).

The morphology of the material surfaces, as well as the qualitative and quantitative compositions of the observed phases, were examined using a scanning electron microscope REMMA 102-02.

\section{Results and discussion}

The phase analysis of the alloys based on powder $\mathrm{X}$-ray diffraction revealed that all the samples contained only the expected phase with hexagonal $\mathrm{Th}_{2} \mathrm{Ni}_{17}$-type structure. For all of the samples we observed a regular expansion of the unit cell with respect to the parent compound, in agreement with the atomic radius of the dopant $\left(r_{\mathrm{Co}}=1.25 \AA\right.$, $r_{\mathrm{Ge}}=1.37 \AA, r_{\mathrm{Al}}=1.43 \AA, r_{\mathrm{Li}}=1.52 \AA, r_{\mathrm{Bi}}=1.56 \AA$, $\left.r_{\mathrm{Sb}}=1.59 \AA, r_{\mathrm{Mg}}=1.60 \AA, r_{\mathrm{Sn}}=1.62 \AA, r_{\mathrm{Ni}}=1.24 \AA\right)$. It should be noticed that in all cases we observed partial replacement of $\mathrm{Ni}$-atoms by lithium, magnesium (or both), aluminum, germanium, antimony, tin, bismuth, and cobalt (Table 1). The EDX-analysis confirmed the formation of solid solutions of substitution on the basis of $\mathrm{Tb}_{2} \mathrm{Ni}_{17}$ exclusively.

The electrochemical hydrogenation of the $\mathrm{NiOOH} \| \mathrm{Tb}_{2} \mathrm{Ni}_{17} \mathrm{H}_{x}$ and $\mathrm{NiOOH} \| \mathrm{Tb}_{2} \mathrm{Ni}_{17-x} M_{x} \mathrm{H}_{y}$ prototype batteries was investigated over 30-50 charge-discharge cycles. In all cases we observed an increase of the volume of the unit cell, as a result of the inclusion of $\mathrm{H}$-atoms into the structure of the initial compound (Table 1). The SEM-images and the results of the EDX-analysis of the electrode materials based on the studied alloys are presented in Fig. 1. As a result of the electrochemical processes, the surface of the electrode material became more porous. For all of the samples we also observed a decrease of the grain size. In the case of the samples doped by $p$-elements (such as $\mathrm{Al}, \mathrm{Ge}$ and $\mathrm{Sb}$ ), or by the mixture $\mathrm{Li}+\mathrm{Mg}$, we observed more significant changes in the morphology of the samples after the electrochemical studies. This may be explained by activation processes, such as etching of the surface and removal of adsorbed gases $\left(\mathrm{O}_{2}, \mathrm{~N}_{2}\right)$ from the surface of the grains. We assume that a thin film of oxides and hydroxides of some active elements interacts with the electrolyte, forming a thin layer on the surface of the grains. This thin layer is destroyed during the first charge-discharge cycles, so that we obtain an active surface with a high amount of pores. We noticed that porous materials better absorb hydrogen, and such activation of the surface also affects the activation of the volume of the grains. We guess that active components of the alloys can interact specifically with the electrolyte to form some oxygen-containing interface on the surface of the material. However, we did not observe any evidence of corrosion. This was confirmed by the absence of additional reflections (from oxides, hydroxides) in the diffraction patterns of the alloys after electrochemical hydrogenation. The changes of the morphology of the electrode surfaces and the grain size, resulting from the electrochemical processes, are presented in Fig. 1. It is worth noticing that the electrodes prepared from the alloys synthesized here were stable over more than 30 , and in some cases more than 50 cycles. The change of the quantitative composition of the phases was also insignificant after hydrogenation.

The electrochemical reactions that occurred on the electrodes in the constructed $\mathrm{Ni}-\mathrm{MH}$ prototype batteries can be presented by the following scheme. The cathode process can be described as follows:

$$
\mathrm{NiOOH}+z \mathrm{H}_{2} \mathrm{O}+z \bar{e} \stackrel{\text { discharge-charge }}{\longleftrightarrow} \mathrm{Ni}(\mathrm{OH})_{2}+z \mathrm{OH}^{-} \text {. }
$$

The potential of this reaction reaches $0.52 \mathrm{~V}$ [1]. At the anodes we observed electrochemical interaction of the $\mathrm{H}$-atoms with $\mathrm{OH}^{-}$-ions. During this reaction the initial intermetallic compounds served as matrix for the storage of hydrogen.

$$
\begin{gathered}
\mathrm{Tb}_{2} \mathrm{Ni}_{17-x} M_{x} \mathrm{H}_{z}+z \mathrm{OH}^{-}-z \bar{e} \stackrel{\text { discharge-charge }}{\longleftrightarrow} \\
\mathrm{Tb}_{2} \mathrm{Ni}_{17-x} M_{x}+z \mathrm{H}_{2} \mathrm{O} .
\end{gathered}
$$

The potential of this reaction is in the range -0.85 to $-0.75 \mathrm{~V}$ [1]. The total battery reaction showed a potential in the range +1.27 to $+1.37 \mathrm{~V}$. The value of the potential of the discharge plateau depends on the amount of intercalated hydrogen and the qualitative and quantitative composition of the electrode materials.

Discharge curves for the studied Ni-MH prototype batteries are presented in Fig. 2. Discharging of the batteries with anode materials on the basis of $\mathrm{Tb}_{2} \mathrm{Ni}_{17}$ or $\mathrm{Tb}_{2} \mathrm{Ni}_{17-x} M_{x}\left(M=\mathrm{Li}, \mathrm{Mg},\left(\mathrm{Li}_{0.4} \mathrm{Mg}_{0.6}\right),\left(\mathrm{Li}_{0.6} \mathrm{Mg}_{0.8}\right)\right.$, $\mathrm{Al}, \mathrm{Ge}, \mathrm{Sn}, \mathrm{Sb}, \mathrm{Bi}, \mathrm{Co}$ ) was carried out at $0.5 \mathrm{~mA}$. The parameter $Q^{30}$ in Table 1 indicates the amount of 
charge at the 30-th discharge cycle (Fig. 2). We can see that the longest times of discharge and voltage correspond to the Li-containing phase and the solid solutions containing a mixture of $\mathrm{Li}$ and $\mathrm{Mg}[41,42]$. The increase of the unit cell volume, improvement of the corrosion resistance, and stability of the formed hydrides observed for these alloys, are the main reasons for the high Coulomb efficiency. The charge process for the electrode samples was carried out at a current of 2.0-2.5 mA. For $\mathrm{Tb}_{2} \mathrm{Ni}_{17}$ and $\mathrm{Tb}_{2} \mathrm{Ni}_{17-x} M_{x}$ with $M=\mathrm{Mg}$ or $\mathrm{Sn}$ we obtained charge-discharge characteristics at $8.0 \mathrm{~mA} \cdot \mathrm{h}$ and $10.0 \mathrm{~mA} \cdot \mathrm{h}$. For the other electrodes the same experiments were carried out at $10.0 \mathrm{~mA} \cdot \mathrm{h}$. In all cases we observed only one plateau, which can be explained as the reaction of intercalation of $\mathrm{H}$-atoms into the structure of the intermetallics without formation of molecular hydrogen $\left(\mathrm{H}_{2}\right)$. The amount of hydrogen was calculated at charge $\left(\mathrm{H}_{\text {charge }}\right)$ and discharge $\left(\mathrm{H}_{\text {discharge }}\right)$ using Faraday's laws. At the conditions of the experiment we obtained hydrides with small amounts of hydrogen because of the low value of charge that passed through the electrochemical system.

During electrochemical hydrogenation hydrogen atoms are formed by dissociation of $\mathrm{H}_{2}$ molecules on the surface of the alloys. Then these atoms penetrate the volume of the material and occupy the octahedral voids of the structure in Wyckoff position $6 h$ (Fig. 3). As a result the volume of the initial structure increases. We assume that at low hydrogen concentration (<3 H/f.u.) only the octahedral voids are involved. The reason for this is the position of the atoms that form the octahedral voids in the structure: four atoms of nickel (or a statistical mixture $(\mathrm{Ni} / M)$ ) are situated in one plane and a large terbium atom is located on each side of the plane. This atom arrangement $(\mathrm{Tb}, M)$ allows increasing the volume of the voids since the atoms are easily displaced when hydrogen atoms enter the voids.

Table 1 Structural and electrochemical characteristics of solid solutions based on $\mathrm{Tb}_{2} \mathrm{Ni}_{17}$ and their hydrides. The Coulomb efficiency of the electrochemical hydrogenation $\bar{\eta}$ is averaged over the first 30-50 cycles, depending on the duration of the experiment.

\begin{tabular}{|c|c|c|c|c|c|c|c|c|}
\hline $\begin{array}{l}\text { Intermetallic / } \\
\text { hydride }\end{array}$ & $a, \AA$ & $c, \AA$ & $V, \AA^{3}$ & $\begin{array}{c}\Delta V / V, \\
\%\end{array}$ & $\begin{array}{l}\mathrm{H}_{\text {charge }} / \\
\text { f.u. }\end{array}$ & $\begin{array}{c}Q^{30} \\
\mathrm{~mA} \cdot \mathrm{h}\end{array}$ & $\begin{array}{l}\mathrm{H}_{\text {discharge }} / \\
\text { f.u. }\end{array}$ & $\begin{array}{l}\bar{\eta} \\
\%\end{array}$ \\
\hline $\begin{array}{c}\mathrm{Tb}_{2} \mathrm{Ni}_{17} \\
\mathrm{~Tb}_{2} \mathrm{Ni}_{17} \mathrm{H}_{x}^{\mathrm{a}}\end{array}$ & $\begin{array}{l}8.3129(5) \\
8.367(1)\end{array}$ & $\begin{array}{l}8.0184(7) \\
8.067(1)\end{array}$ & $\begin{array}{r}479.87(5) \\
489.1(1)\end{array}$ & 1.92 & 1.10 & 5.35 & $\begin{array}{c}0.67 \\
(0.55)\end{array}$ & 50.0 \\
\hline $\begin{array}{c}\mathrm{Tb}_{2} \mathrm{Ni}_{15.5} \mathrm{Li}_{1.5} \\
\mathrm{~Tb}_{2} \mathrm{Ni}_{15.5} \mathrm{Li}_{1.5} \mathrm{H}_{x}\end{array}$ & $\begin{array}{l}8.3148(2) \\
8.3540(3)\end{array}$ & $\begin{array}{l}8.0388(3) \\
8.0624(5)\end{array}$ & $\begin{array}{l}481.32(2) \\
487.29(3)\end{array}$ & 1.24 & 1.66 & 8.90 & 1.43 & 86.0 \\
\hline $\begin{array}{c}\mathrm{Tb}_{2} \mathrm{Ni}_{16} \mathrm{Li}_{0.4} \mathrm{Mg}_{0.6} \\
\mathrm{~Tb}_{2} \mathrm{Ni}_{16} \mathrm{Li}_{0.4} \mathrm{Mg}_{0.6} \mathrm{H}_{x}\end{array}$ & $\begin{array}{l}8.3115(2) \\
8.344(1)\end{array}$ & $\begin{array}{l}8.0286(3) \\
8.051(2)\end{array}$ & $\begin{array}{r}480.32(2) \\
485.5(1)\end{array}$ & 1.08 & 1.60 & 9.15 & 1.46 & 91.5 \\
\hline $\begin{array}{c}\mathrm{Tb}_{2} \mathrm{Ni}_{15.6} \mathrm{Li}_{0.6} \mathrm{Mg}_{0.8} \\
\mathrm{~Tb}_{2} \mathrm{Ni}_{15.6} \mathrm{Li}_{0.6} \mathrm{Mg}_{0.8} \mathrm{H}_{x}\end{array}$ & $\begin{array}{l}8.3129(4) \\
8.3488(5)\end{array}$ & $\begin{array}{l}8.0384(4) \\
8.0593(6)\end{array}$ & $\begin{array}{l}481.08(4) \\
486.49(6)\end{array}$ & 1.12 & 1.58 & $\sim 9.50$ & 1.50 & 95.0 \\
\hline $\begin{array}{c}\mathrm{Tb}_{2} \mathrm{Ni}_{15.5} \mathrm{Mg}_{15.5} \\
\mathrm{~Tb}_{2} \mathrm{Ni}_{15.5} \mathrm{Mg}_{15.5} \mathrm{H}_{x}{ }^{\mathrm{a}}\end{array}$ & $\begin{array}{l}8.335(1) \\
8.380(1)\end{array}$ & $\begin{array}{l}8.063(2) \\
8.083(2)\end{array}$ & $\begin{array}{l}485.2(1) \\
491.7(1)\end{array}$ & 1.34 & 1.49 & 7.65 & $\begin{array}{l}1.37 \\
(1.14)\end{array}$ & 76.3 \\
\hline $\begin{array}{c}\mathrm{Tb}_{2} \mathrm{Ni}_{16} \mathrm{Al} \\
\mathrm{Tb}_{2} \mathrm{Ni}_{16} \mathrm{AlH}{ }_{x}\end{array}$ & $\begin{array}{l}8.3677(4) \\
8.425(2)\end{array}$ & $\begin{array}{l}7.9965(6) \\
8.037(2)\end{array}$ & $\begin{array}{l}484.89(5) \\
494.0(2)\end{array}$ & 1.88 & 1.61 & 7.00 & 1.09 & 67.8 \\
\hline $\begin{array}{c}\mathrm{Tb}_{2} \mathrm{Ni}_{16} \mathrm{Ge} \\
\mathrm{Tb}_{2} \mathrm{Ni}_{16} \mathrm{GeH}_{x}\end{array}$ & $\begin{array}{l}8.3323(7) \\
8.3836(8)\end{array}$ & $\begin{array}{l}8.0395(9) \\
8.0694(9)\end{array}$ & $\begin{array}{l}483.39(7) \\
491.17(7)\end{array}$ & 1.61 & 1.66 & 6.10 & 1.05 & 63.1 \\
\hline $\begin{array}{c}\mathrm{Tb}_{2} \mathrm{Ni}_{16} \mathrm{Sn} \\
\mathrm{Tb}_{2} \mathrm{Ni}_{16} \mathrm{SnH}_{x}^{\mathrm{a}}\end{array}$ & $\begin{array}{l}8.356(2) \\
8.380(2)\end{array}$ & $\begin{array}{l}8.126(4) \\
8.143(3)\end{array}$ & $\begin{array}{l}491.4(3) \\
495.2(2)\end{array}$ & 0.77 & 1.20 & 5.70 & $\begin{array}{c}0.76 \\
(0.63)\end{array}$ & 52.5 \\
\hline $\begin{array}{c}\mathrm{Tb}_{2} \mathrm{Ni}_{15.8} \mathrm{Sb}_{1.2} \\
\mathrm{~Tb}_{2} \mathrm{Ni}_{15.8} \mathrm{Sb}_{1.2} \mathrm{H}_{x}\end{array}$ & $\begin{array}{l}8.3893(4) \\
8.4383(6)\end{array}$ & $\begin{array}{l}8.0907(6) \\
8.142(1)\end{array}$ & $\begin{array}{l}493.14(4) \\
502.09(7)\end{array}$ & 1.81 & 1.64 & 7.60 & 1.24 & 75.5 \\
\hline $\begin{array}{c}\mathrm{Tb}_{2} \mathrm{Ni}_{16.2} \mathrm{Bi}_{0.8} \\
\mathrm{~Tb}_{2} \mathrm{Ni}_{16.2} \mathrm{Bi}_{0.8} \mathrm{H}_{x}\end{array}$ & $\begin{array}{l}8.3434(9) \\
8.388(1)\end{array}$ & $\begin{array}{l}8.052(1) \\
8.056(1)\end{array}$ & $\begin{array}{l}485.4(1) \\
491.0(1)\end{array}$ & 1.15 & 1.83 & 7.75 & 1.46 & 79.8 \\
\hline $\begin{array}{c}\mathrm{Tb}_{2} \mathrm{Ni}_{12} \mathrm{Co}_{5} \\
\mathrm{~Tb}_{2} \mathrm{Ni}_{12} \mathrm{Co}_{5} \mathrm{H}_{x}\end{array}$ & $\begin{array}{l}8.3476(7) \\
8.374(2)\end{array}$ & $\begin{array}{l}8.041(1) \\
8.077(3)\end{array}$ & $\begin{array}{c}485.25(9) \\
490.5(2)\end{array}$ & 1.08 & 1.65 & 6.00 & 0.98 & 59.5 \\
\hline
\end{tabular}

\footnotetext{
${ }^{\mathrm{a}}$ The results at $8 \mathrm{~mA} \cdot \mathrm{h}$ were published in $[33,34]$, the values of $\mathrm{H} / \mathrm{f} . \mathrm{u}$. at this charge are given in parentheses.
} 
The amount of intercalated hydrogen in the structure is not large; the maximal amount should be obtained at a larger electric charge (in the case of electrochemical hydrogenation) or higher pressure of hydrogen (in the case of gas hydrogenation). In both cases we observed the formation of a solid solution of inclusion of $\mathrm{H}$-atoms into the structure of the $\mathrm{Tb}_{2} \mathrm{Ni}_{17-x} M_{x}$ phases. We assume that the tetrahedral voids $12 i$, together with the octahedral voids $6 h$, can be occupied during gas hydrogenation. The tetrahedral voids have smaller size than the octahedral ones but consist of only Ni-atoms (or atoms of the statistical mixture $(\mathrm{Ni}, M))$. The coordination polyhedron of the $\mathrm{H}$-atoms in the structure of $\mathrm{Tb}_{2} \mathrm{Ni}_{17-x} M_{x} \mathrm{H}_{y}$ is an octahedron $\left[\mathbf{H T b}_{2} M_{4}\right]$ for $y<3$ and a tetrahedron $\left[\mathbf{H} M_{4}\right]$ for $y>3$ (Fig. 3).
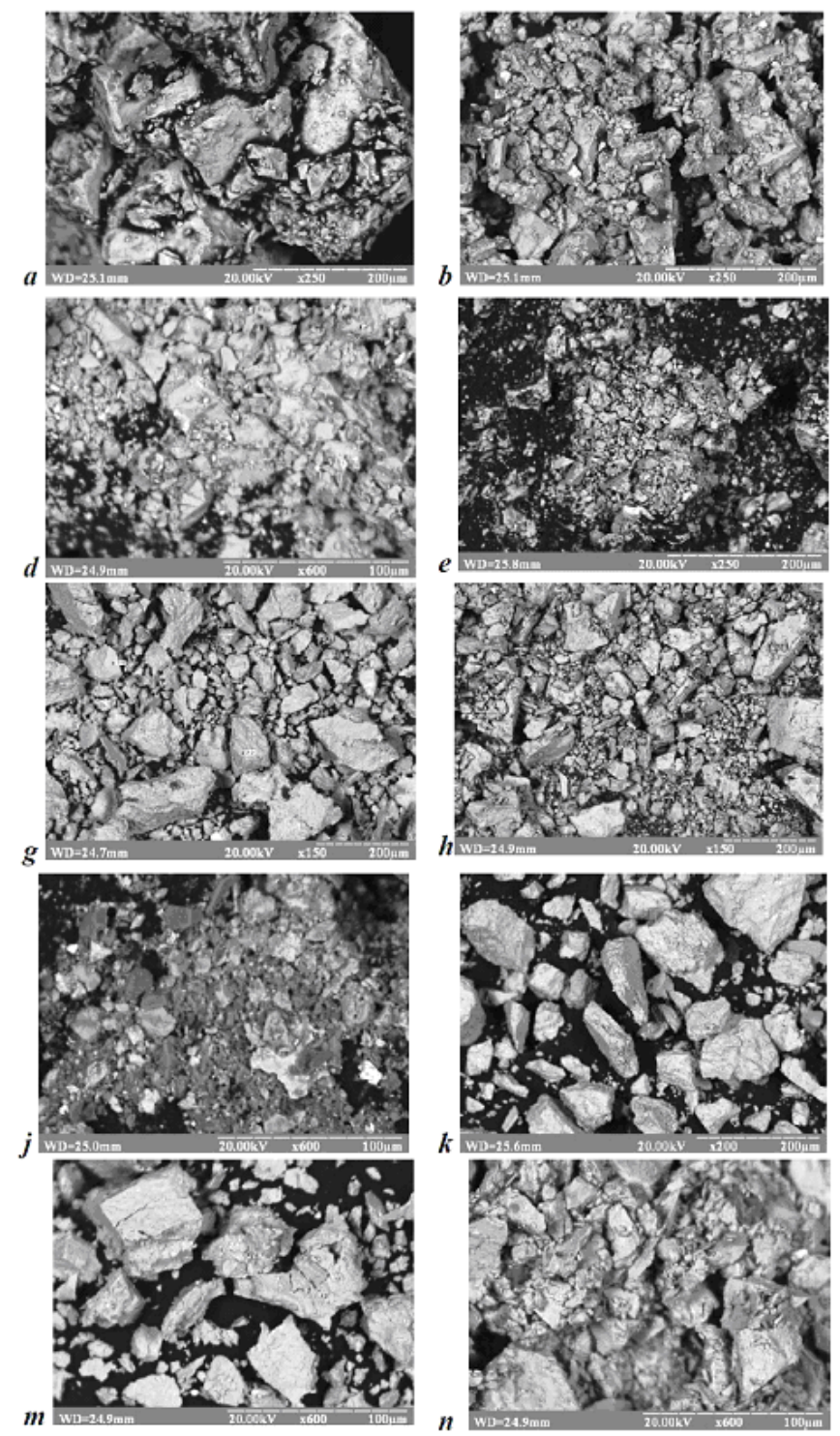
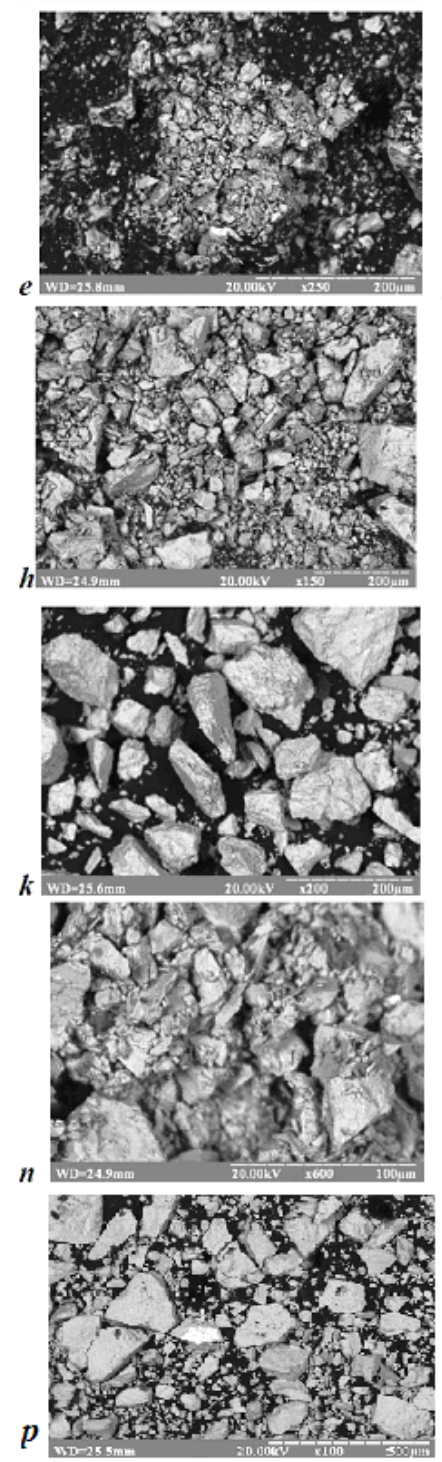
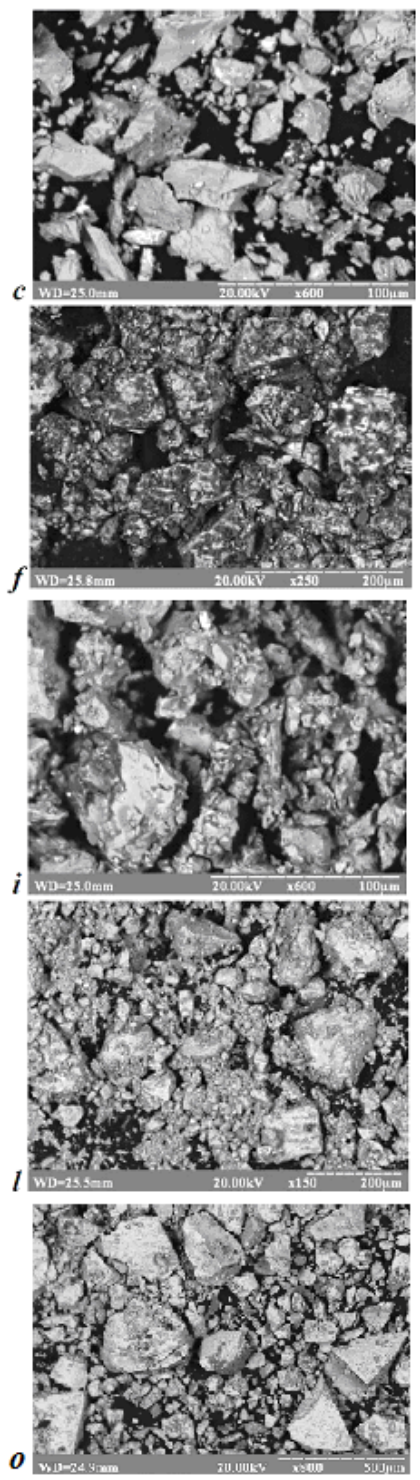

Fig. 1 SEM-images of the anode materials before $(*)$ and after $(* *)$ 30-50 cycles of electrochemical hydrogenation: $\mathrm{Tb}_{11.37} \mathrm{Ni}_{88.63} *(a), \mathrm{Tb}_{11.40} \mathrm{Ni}_{88.60} * *(b), \mathrm{Tb}_{9.68} \mathrm{Ni}_{85.77} \mathrm{Mg}_{4.55} *$ (c), $\mathrm{Tb}_{10.84} \mathrm{Ni}_{83.83} \mathrm{Mg}_{5.33} * *$ (d), $\mathrm{Tb}_{10.83} \mathrm{Ni}_{85.74} \mathrm{Mg}_{3.43} *(e), \quad \mathrm{Tb}_{11.05} \mathrm{Ni}_{85.28} \mathrm{Mg}_{3.67} * * \quad(f), \quad \mathrm{Tb}_{9.85} \mathrm{Ni}_{84.40} \mathrm{Al}_{5.75}{ }^{*}(g), \quad \mathrm{Tb}_{10.21} \mathrm{Ni}_{85.53} \mathrm{Al}_{4.26} * * \quad(h)$, $\mathrm{Tb}_{11.63} \mathrm{Ni}_{84.15} \mathrm{Ge}_{4.23} *(i), \quad \mathrm{Tb}_{11.26} \mathrm{Ni}_{86.38} \mathrm{Ge}_{2.35} * * \quad(j), \quad \mathrm{Tb}_{11.24} \mathrm{Ni}_{82.28} \mathrm{Sb}_{6.48} * \quad(k), \quad \mathrm{Tb}_{11.62} \mathrm{Ni}_{82.56} \mathrm{Sb}_{5.82} * * \quad(l)$, $\mathrm{Tb}_{10.87} \mathrm{Ni}_{65.33} \mathrm{Co}_{23.80} *(m), \mathrm{Tb}_{10.76} \mathrm{Ni}_{65.35} \mathrm{Co}_{25.89} * *(n), \mathrm{Tb}_{10.31} \mathrm{Ni}_{87.07} \mathrm{Bi}_{2.62} *(o), \mathrm{Tb}_{12.96} \mathrm{Ni}_{84.34} \mathrm{Bi}_{2.70} * *(p)$. 


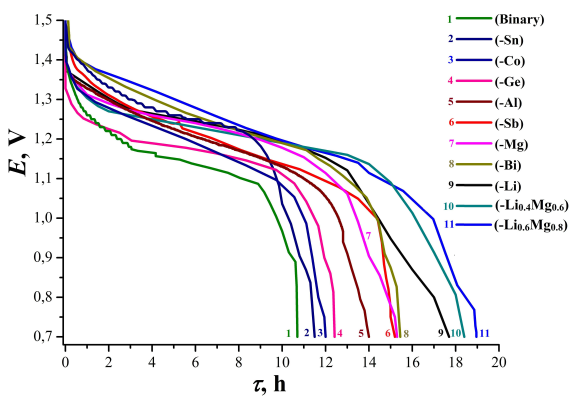

Fig. 2 Discharge curves (30-th cycle) for the systems $\mathrm{NiOOH} / / \mathrm{Tb}_{2} \mathrm{Ni}_{17} M_{x} \mathrm{H}_{y}, M=\mathrm{Li}, \mathrm{Mg}$, $\mathrm{Li}_{0.4} \mathrm{Mg}_{0.6}, \mathrm{Li}_{0.6} \mathrm{Mg}_{0.8}, \mathrm{Al}, \mathrm{Ge}, \mathrm{Sn}, \mathrm{Sb}, \mathrm{Bi}$ and Co in galvanostatic regime at $0.5 \mathrm{~mA}$.

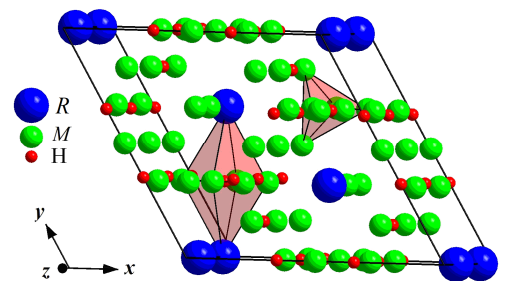

Fig. 3 Unit cell of $\mathrm{Tb}_{2} \mathrm{Ni}_{17-x} M_{x} \mathrm{H}_{y}$ hydrides (if $y<3$ the H-atoms occupy the octahedral $6 h$ voids; if $y>3$ additional tetrahedral $12 i$ voids are filled with $\mathrm{H}$-atoms) [26].

Multi-cycle chronopotentiometric data for the Ni-MH prototype battery (Fig. 4) confirmed the stability of the electrode materials on the basis of $\mathrm{Tb}_{2} \mathrm{Ni}_{16} \mathrm{Li}_{0.4} \mathrm{Mg}_{0.6}, \mathrm{~Tb}_{2} \mathrm{Ni}_{15.6} \mathrm{Li}_{0.6} \mathrm{Mg}_{0.8}, \mathrm{~Tb}_{2} \mathrm{Ni}_{16} \mathrm{Al}$ and $\mathrm{Tb}_{2} \mathrm{Ni}_{12} \mathrm{Co}_{5}$ alloys over 20 cycles, and the similar behavior of these phases. The alloys with the statistical mixture ( $\mathrm{Li}, \mathrm{Mg}$ ) or $\mathrm{Al}$ as doping component showed better results than those with Co.

To confirm the stability of the studied alloys we carried out voltamperometric and impedance measurements and obtained the cyclic voltammetric and potentio-kinetic polarized curves shown in Figs. 5 and 6. On the cyclic voltamperograms (Fig. 5) we did not observe any significant interaction of the samples in the cathode and anode regions. The most stable alloys are those doped by $\mathrm{Al}$ or $\mathrm{Li}$ and $\mathrm{Mg}$ simultaneously. Moreover, the alloy containing the larger amounts of $\mathrm{Li}$ and $\mathrm{Mg}$ was more stable in the electrolyte. For the Al-containing electrode material the potential of corrosion was $E_{\text {corr }}=-0.565 \mathrm{~V}$, for $\mathrm{Tb}_{2} \mathrm{Ni}_{16} \mathrm{Li}_{0.4} \mathrm{Mg}_{0.6} \quad E_{\text {corr }}=-0.410 \mathrm{~V}, \quad$ for $\mathrm{Tb}_{2} \mathrm{Ni}_{16} \mathrm{Li}_{0.6} \mathrm{Mg}_{0.8} \quad E_{\text {corr }}=-0.550 \mathrm{~V}$; for the Co-containing phase the potential of corrosion was $-0.420 \mathrm{~V}$ (Fig. 6). These alloys are stable in $6 \mathrm{M} \mathrm{KOH}$ in the range of potential $-0.5(-0.4) \ldots+0.4(+0.8) \mathrm{V}$. Impedance studies of the $\mathrm{Tb}_{2} \mathrm{Ni}_{15.6} \mathrm{Li}_{0.6} \mathrm{Mg}_{0.8}$ alloy confirmed its stability and showed a logical decrease of the resistance at the electrode layer with increasing potential. The best diffusion of hydrogen into the structure was observed at the higher potential (0.9 V) (Fig. 7).
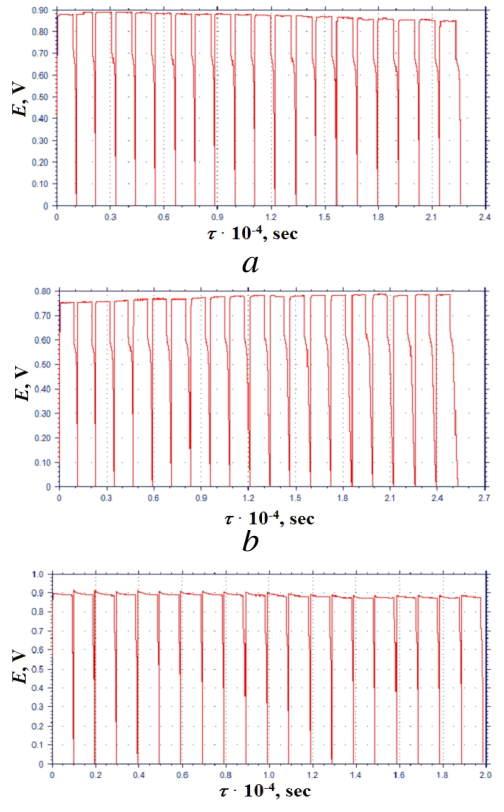

$c$

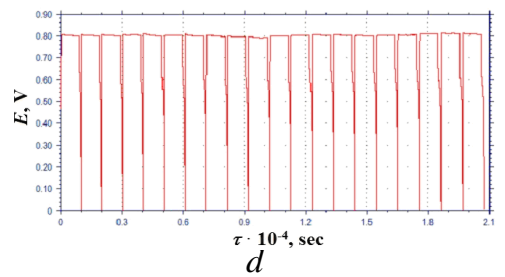

Fig. 4 Multi-cycle chronopotentiometric data for $\mathrm{Ni}-\mathrm{MH}$ prototype batteries with anode materials on the basis of $\mathrm{Tb}_{2} \mathrm{Ni}_{16} \mathrm{Li}_{0.4} \mathrm{Mg}_{0.6}(a)$, $\mathrm{Tb}_{2} \mathrm{Ni}_{15.6} \mathrm{Li}_{0.6} \mathrm{Mg}_{0.8} \quad(b), \quad \mathrm{Tb}_{2} \mathrm{Ni}_{16} \mathrm{Al} \quad(c)$, and $\mathrm{Tb}_{2} \mathrm{Ni}_{12} \mathrm{Co}_{5}(d)$ alloys.

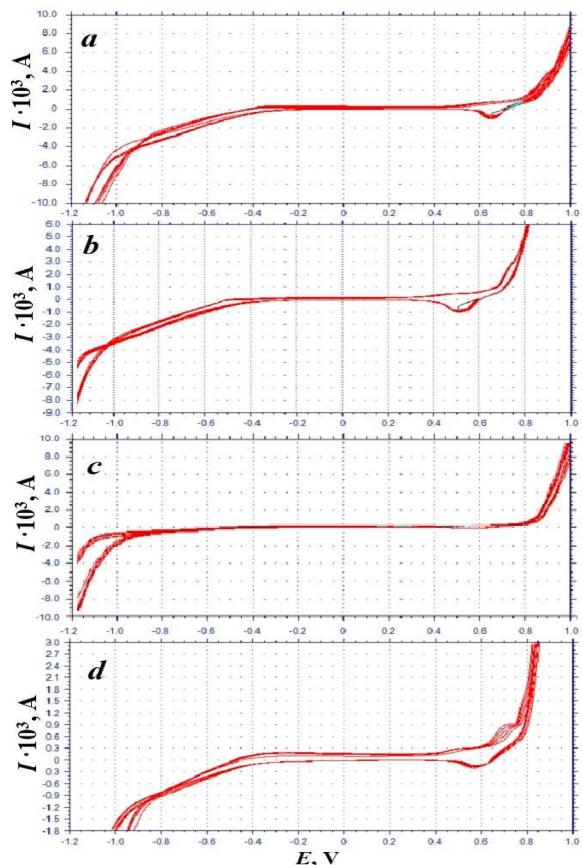

Fig. 5 Cyclic voltammetric dependencies for electrodes on the basis of $\mathrm{Tb}_{2} \mathrm{Ni}_{16} \mathrm{Li}_{0.4} \mathrm{Mg}_{0.6}(a)$, $\mathrm{Tb}_{2} \mathrm{Ni}_{15.6} \mathrm{Li}_{0.6} \mathrm{Mg}_{0.8} \quad(b), \quad \mathrm{Tb}_{2} \mathrm{Ni}_{16} \mathrm{Al} \quad(c)$, and $\mathrm{Tb}_{2} \mathrm{Ni}_{12} \mathrm{Co}_{5}(d)$ alloys. 


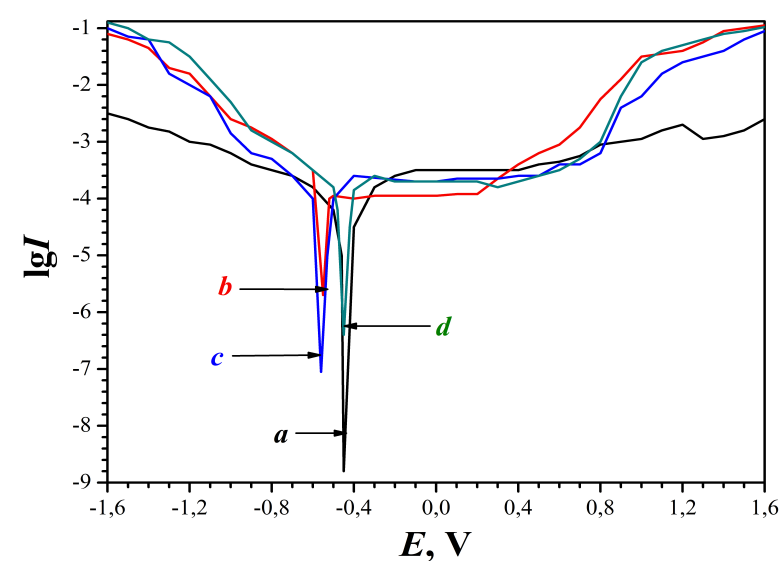

Fig. 6 Potentio-kinetic polarized curves for electrodes based on the $\mathrm{Tb}_{2} \mathrm{Ni}_{16} \mathrm{Li}_{0.4} \mathrm{Mg}_{0.6}(a)$, $\mathrm{Tb}_{2} \mathrm{Ni}_{15.6} \mathrm{Li}_{0.6} \mathrm{Mg}_{0.8} \quad(b), \quad \mathrm{Tb}_{2} \mathrm{Ni}_{16} \mathrm{Al} \quad(c)$, and $\mathrm{Tb}_{2} \mathrm{Ni}_{12} \mathrm{Co}_{5}(d)$ alloys.

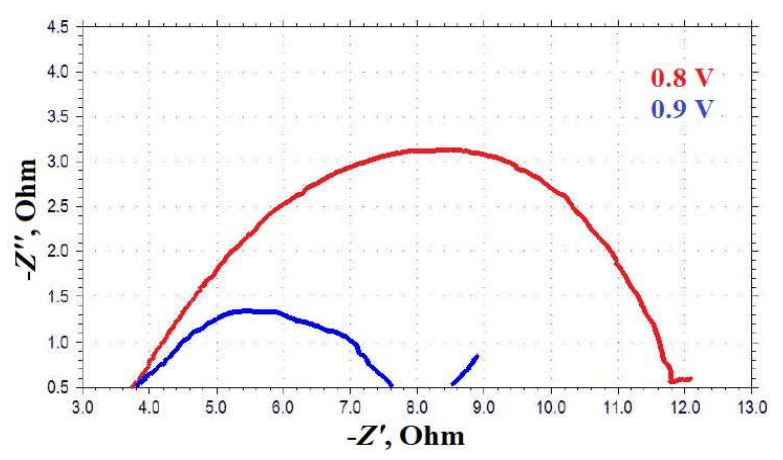

Fig. 7 Impedance for the electrode based on $\mathrm{Tb}_{2} \mathrm{Ni}_{15.6} \mathrm{Li}_{0.6} \mathrm{Mg}_{0.8}$.

During the charge process a charge of $10 \mathrm{~mA} \cdot \mathrm{h}$ passed through the prototype battery. The binary phase $\mathrm{Tb}_{2} \mathrm{Ni}_{17}$ absorbed the smallest amount of hydrogen and showed a hydrogenation efficiency of about $50 \%$. The largest efficiency of electrochemical hydrogenation, which reached $95.0 \%$ (averaging over the first 50 cycles), was observed for the alloy containing a combination of $\mathrm{Li}$ and $\mathrm{Mg}$ at the composition $\mathrm{Tb}_{2} \mathrm{Ni}_{15.6} \mathrm{Li}_{0.6} \mathrm{Mg}_{0.8}$. Lower Coulomb efficiency $(91.5 \%)$ was observed for the sample $\mathrm{Tb}_{2} \mathrm{Ni}_{16} \mathrm{Li}_{0.4} \mathrm{Mg}_{0.6}$ with smaller amounts of $\mathrm{Li}$ and $\mathrm{Mg}$. An additive effect was observed when we used simultaneously lithium and magnesium as dopants, since the alloy containing lithium exhibited $86.0 \%$ Coulomb efficiency and the alloy containing magnesium $76.3 \%$ Coulomb efficiency. The phases with $p$-elements ( $\mathrm{Al}, \mathrm{Ge}$ and $\mathrm{Sn}$ ) as dopants showed a relatively low amount of absorbed hydrogen and the values of the efficiency were 67.7, 63.1 and 52.5\%, respectively. The phases with such $p$-elements as $\mathrm{Sb}$, $\mathrm{Bi}$ formed solutions $\mathrm{Tb}_{2} \mathrm{Ni}_{17-x} M_{x} \mathrm{H}_{y}$ of the inclusion type with larger amounts of hydrogen and showed $75.5 \%$ and $79.8 \%$ efficiency. Co as doping component caused little improvement of the efficiency
( $59.5 \%$ for 26.3 at.\% Co), compared to the binary $\mathrm{Tb}_{2} \mathrm{Ni}_{17}$ phase.

Among the advantages of the electrode materials on the basis of phases with $\mathrm{Th}_{2} \mathrm{Ni}_{17}$-type structure is their lower price, because the amount of rare-earth metal in these phases is 10.5 at.\%, while in commercial batteries based on phases with $\mathrm{CaCu}_{5^{-}}$ type structure the content of rare-earth metal is 16.7 at.\%. However, the maximum amount of absorbed hydrogen reaches $4 \mathrm{H} / \mathrm{f}$.u., which is less than for $\mathrm{LaNi}_{5}(6 \mathrm{H} / \mathrm{f} . \mathrm{u})$. This hydrogen content is equivalent to a capacity of $85 \mathrm{~mA} \cdot \mathrm{h} / \mathrm{g}$ for electrochemical hydrogenation. The phases studied here are stable in alkaline solutions of electrolyte $(6 \mathrm{M}$ $\mathrm{KOH})$, keep the crystallinity of the electrode materials during the electrochemical processes, and preserve the structure of the initial compounds. This makes them perspective materials for accumulation of hydrogen and as electrode materials in Ni-MH batteries.

\section{Conclusions}

During the study of the electrochemical hydrogenation of the phases $\mathrm{Tb}_{2} \mathrm{Ni}_{17-x} M_{x}, x \approx 1(M=\mathrm{Li}, \mathrm{Mg}, \mathrm{Al}, \mathrm{Ge}$, $\mathrm{Sn}, \mathrm{Sb}, \mathrm{Bi}, \mathrm{Co}$ ), we observed that the amount of electric charge has no significant influence on the Coulomb efficiency, but affects the quantity of intercalated hydrogen. The $\mathrm{H}_{\text {discharge }} / \mathrm{H}_{\text {charge }}$ ratio (efficiency of the hydrogenation) for the electrodes based on the pure binary $\mathrm{Tb}_{2} \mathrm{Ni}_{17}$ phase, or ternary $\mathrm{Mg}$ - or Sn-containing phases, was similar at 8.0 and $10.0 \mathrm{~mA} \cdot \mathrm{h}$. Generally, the increase of the volume of the unit cell depends on the amount of intercalated $\mathrm{H}$ atoms, but, because of the weak diffusion of $\mathrm{H}$-atoms during discharge, we observed a low amount of $\mathrm{H}_{\text {discharge }} /$ f.u. Another reason for this can be undesired electrochemical reactions, for example the formation of molecular hydrogen.

Lithium, magnesium, rare earths and some transition metals have the ability to absorb hydrogen, and a combination of these elements, forming multi-component alloys, could probably be better materials for negative electrodes in $\mathrm{Ni}-\mathrm{MH}$ batteries. The solid solution with the composition $\mathrm{Tb}_{2} \mathrm{Ni}_{16} \mathrm{Li}_{0.6} \mathrm{Mg}_{0.8}$ showed better properties $(95.0 \%$ Coulomb efficiency) than the alloy $\mathrm{Tb}_{2} \mathrm{Ni}_{16} \mathrm{Li}_{0.4} \mathrm{Mg}_{0.6}$ (91.5\% Coulomb efficiency) and the other solid solutions. This encourages us to continue the experimental work in this direction, with the purpose to create new electrode materials with improved characteristics.

\section{Acknowledgements}

Funding for this research was provided by the Ministry of Education and Science of Ukraine (grant No. 0115U003257) and National Science Center of Poland (grant No. 2014/15/B/ST8/00101). 


\section{References}

[1] J.O. Besenhard, Handbook of Battery Materials, Wiley-VCH, Weinheim, 1999, 1023 p.

[2] C.A. Vincent, B. Scrosati, Modern Batteries: an Introduction to Electrochemical Power Sources: 2nd Ed., Arnold, London, 1997, 351 p.

[3] M.H. Mintz, I. Jacob, D. Shaltiel, Experimental Techniques II: Adapatation of New Techniques to Study Surface and Bulk Properties of H-Metal Systems, In: L. Schlapbach (Ed.), Hydrogen in Intermetallic Compounds II, Springer, Berlin, 1992, pp. 285-317.

[4] J.M. Ogden, J. Hydrog. Energy 24(8) (1999) 709-730.

[5] R.C. Weast, M.J. Astle, W.H. Beyer (Eds.), CRC Handbook of Chemistry and Physics, 64th Ed., CRC Press, Boca Raton, FL, 1983, 2303 p.

[6] M.L. Trudeau, MRS Bull. 24 (1999) 23-26.

[7] V. Yartys, R. Denys, Chem. Met. Alloys. 7(1/2) (2014) 1-8.

[8] V. Shtender, V. Paul-Boncour, R. Denys, I. Zavaliy, Visn. Lviv. Univ., Ser. Khim. 56(1) (2015) 138-144.

[9] V.V. Shtender, V. Paul-Boncour, A.B. Riabov, R.V. Denys, I.Yu. Zavaliy, J. Solid State Chem. 229 (2015) 135-140.

[10] A. Stetskiv, B. Rozdzynska-Kiełbik, G. Kowalczyk, W. Prochwicz, P. Siemion, V. Pavlyuk, Solid State Sci. 38 (2014) 35-41.

[11] K. Giza, W. Iwasieczko, V.V. Pavlyuk, H. Bala, H. Drulis, L. Adamczyk, J. Alloys Compd. 429 (2007) 352-356.

[12] L. Wang, H. Yuan, H. Yang, K. Zhou, D. Song, Y. Zhang, J. Alloys Compd. 302 (2000) 65-69.

[13] A. Percheron-Guégan, C. Lartigue, J.C. Achard, P. Germi, F. Tasset, J. Less-Common Met. 74 (1980) 1-12.

[14] J.M. Joubert, M. Latroche, R. Cerny, R.C. Bowman Jr., A. Percheron-Guégan, K. Yvon, J. Alloys Compd. 293-295 (1999) 124-129.

[15] J.M. Joubert, M. Latroche, R.C. Bowman Jr., A. Percheron-Guégan, F. Bourée-Vigneron, Appl. Phys. A 74(Suppl. 1) (2002) 1037-1039.

[16] K. Giza, W. Iwasieczko, V.V. Pavlyuk, H. Bala, H. Drulis, J. Power Sources 181 (2008) 38-40.

[17] V.V. Pavlyuk, I.M. Opainych, O.I. Bodak, T. Palasinska, B. Rozdzynska, H. Bala, Pol. J. Chem. 71 (1997) 309-313.

[18] S. De Negri, P. Solokha, A. Saccone, V. Pavlyuk, Intermetallics 16 (2008) 168-178.

[19] B. Rozdzynska-Kielbik, W. Iwasieczko, H. Drulis, V.V. Pavlyuk, H. Bala, J. Alloys Compd. 298 (2000) 237-243.

[20] K. Giza, H. Bala, V.V. Pavlyuk, Mater. Corros. 60 (2009) 29-33.

[21] K. Giza, W. Iwasieczko, H. Bala, V.V. Pavlyuk, H. Drulis, Int. J. Hydrog. Energy 34 (2009) 913-915.
[22] O.Ya. Makaryk, G.S. Dmytriv, D.G. Kevorkov, V.V. Pavlyuk, J. Alloys Compd. 317-318 (2001) 448-449.

[23] V. Levytskyy, V. Babizhetskyy, O. Myakush, B. Kotur, I. Koval'chuk, Chem. Met. Alloys 7(1/2) (2014) 26-31.

[24] I. Tereshina, S. Nikitin, W. Suski, J. StepienDamm, W. Iwasieczko, H. Drulis, K. Skokov, J. Alloys Compd. 404-406 (2005) 172-175.

[25] S. Wirth, R. Skomski, J.M.D. Coey, Phys. Rev. B 55 (1997) 5700-5707.

[26] O. Isnard, S. Miraglia, J.L. Soubeyroux, D. Fruchart, A. Stergiou, J. Less-Common Met. 162 (1990) 273-284.

[27] I. Pop, V. Crigan, M. Coldea, C. Hagan, G. Borodi, Phys. B 130 (1985) 504.

[28] J. Laforest, R. Lemaire, D. Paccard, R. Pauthenet, C. R. Hebd. Seances Acad. Sci. 264 (1967) 676.

[29] E. Burzo, J. Laforest, C. R. Acad. Sci. 274 (1972) 114.

[30] I. Pop, C. Hagan, J. Magn. Magn. Mater. 66 (1987) 385-389.

[31] W. Suski, N. Vityk, R. Gladyshevskii, A. Gilewski, T. Mydlarz, K. Wochowski, Chem. Met. Alloys 1 (2008) 111-114.

[32] P.G. Solokha, PhD thesis, Lviv, 2008, 244 p.

[33] V.M. Kordan, V.V. Nytka, O.Ya. Zelinska, V.V. Pavlyuk, R.Ya. Serkiz, Coll. Abstr. XIII Int. Conf. Cryst. Chem. Intermet. Compd., Lviv, 2016, p. 125.

[34] V. Kordan, O. Zelinska, V. Pavlyuk, V. Nytka, R. Serkiz, Chem. Met. Alloys 9(3/4) (2016) 153-157.

[35] V.M. Kordan, V.V. Pavlyuk, O.Ya. Zelinska, R.Ya. Serkiz, Abstr. IX Ukr. Sci. Conf. Stud. Young Scientists "Current Problems in Chemistry”, Vinnytsia, 2016, p. 73.

[36] V. Pavlyuk, W. Ciesielski, D. Kulawik, G. Kowalczyk, A. Balińska, W. Prochwicz, A. Folentarska, N. Pavlyuk, V. Kordan, Coll. Abstr. XIII Int. Conf. Cryst. Chem. Intermet. Compd. Lviv, 2016, p. 121.

[37] N. Pavlyuk, G. Dmytriv, V. Kordan, G. Kowalczyk, Abstr. VIII All-Ukr. Sci. Conf. Stud. Postgrad. "Karazin Chemical Readings 2017”, Kharkiv, 2017, pp. 27-28.

[38] G. King, D. Schwarzenbach, LATCON, Xtal 3.7 System, University of Western Australia, 2000.

[39] W. Kraus, G. Nolze, Powder Cell for Windows, Berlin, 1999.

[40] http://chem.lnu.edu.ua/mtech/mtech.htm

[41] V.M. Kordan, V.V. Nytka, O.Ya. Zelinska, V.V. Pavlyuk, R.Ya. Serkiz, Abstr. IX Ukr. Sci. Conf. Stud. Young Scientists "Current Problems in Chemistry”, Vinnytsia, 2017, 90.

[42] V. Kordan, V. Nytka, O. Zelinska, I. Tarasiuk, I. Oshchapovsky, V. Pavlyuk, R. Serkiz, Coll. Sci. Abstr. XVI Sci. Conf. "Lviv Chemisty Readings 2017”, Lviv, 2017, H51 (in Ukrainian). 